Research Article

\title{
A Study during COVID-I9 Pandemic among People for Attitude towards Face Mask, Social Distancing and Safe Practices in Pilkhuwa, UP, India
}

\author{
$\underline{\text { Ritika Kansal', Amit Joon }}$, Desh Pal Singh ${ }^{3}, \underline{\text { S Kumar }}{ }^{4}$ \\ ${ }^{1}$ Assistant Professor, Department of Pathology Saraswathi Medical College, Pilkhuwa, Hapur, Uttar Pradesh, India. \\ ${ }^{2}$ Assistant Professor, Department of Community Medicine, G.S Medical College, Pilkhuwa, Hapur, Uttar Pradesh, India. \\ ${ }^{3}$ Associate Professor, Department of Surgery, Saraswathi Medical College, Pilkhuwa, Hapur, Uttar Pradesh, India. \\ ${ }^{4}$ Chief Medical Superintendent \& Professor Anesthesiology \& Critical Care, G.S Medical College \& Hospital, Pilkhuwa, Hapur, \\ Uttar Pradesh, India.
}

DOI: https://doi.org/10.24321/2455.9199.202102

I $\quad \mathbf{N} \quad \mathbf{F} \mathbf{O}$

Corresponding Author:

Amit Joon, Department of Community Medicine, G.S Medical College, Pilkhuwa, Hapur, Uttar Pradesh, India.

E-mail Id:

dramitjoon@gmail.com

Orcid Id:

https://orcid.org/0000-0003-1033-5333

How to cite this article:

Kansal R, Joon A, Singh D, Kumar S. A Study during COVID-19 Pandemic among People for Attitude towards Face Mask, Social Distancing and Safe Practices in Pilkhuwa, UP, India. Int J HealthCare Edu \& Med Inform. 2021;8(2):1-5.

Date of Submission: 2021-03-15

Date of Acceptance: 2021-06-06

\section{$\begin{array}{lllllllllllll}\mathbf{A} & \mathbf{B} & \mathbf{S} & \mathbf{T} & \mathbf{R} & \mathbf{A} & \mathbf{C} & \mathbf{T}\end{array}$}

Background: In spite of the vaccination available for COVID-19, the importance of non-pharmacological interventions (NPIs) methods became very significant in control and prevention of COVID-19 infection. Since the government of India issued phase-wise nationwide unlock, a drastic change in growth rate of the cases was observed. This study was conducted to ascertain the practice and attitude towards the use of face mask, social distancing and safe measures by people in public with their understanding to have informeds insight regarding the growth of COVID-19.

Methods: This observational qualitative study was carried out at public places in Pilkhuwa, Hapur, UP, India from 31st March 2020 to 1st April 2021. A total of 300 people were observed. Data were collected from different public (crowded) areas. Collected data were segregated into the segment based on research question and analyzed using qualitative content analysis. People were not engaged in designing the study, research questions, setting understanding or evaluating results, or research reporting.

Results: People have a different attitude towards the use of face mask, social distancing, safe measure and different knowledge or understanding regarding COVID-19 and prevention.

Conclusion: The confusion is due to information pollution, new unfamiliar practices, serious disease (high mortality), attack on freedom and diversion of the real issue in understanding the ongoing health crisis and disobedient attitude towards the preventive measures.

Keywords: covID-19, Attitude, Safe Practices, Social Distancing, Facemask 


\section{Introduction}

The COVID-19 disease, caused by the infection of SARS CoV2 was first reported in Wuhan, China in December 2019, modern globally connected world made the virus quickly spread across multiple countries. In India, the first case was reported on Jan 31, 2020. During present COVID-19 pandemic period, in spite of the vaccination available for COVID-19, the importance of non-pharmacological interventions (NPIs) methods is very significant in the control/prevention of COVID-19 infection.

NPIs at population level including travel suspension and national crisis response were helpful to flatten the epidemic bend of COVID-19 in China. ${ }^{1}$ Similar practice and lockdown was enforced in India. ${ }^{2,3}$ Nationwide phase-wise unlock had drastic changes in the growth rate of cases observed.

A study of practice attitude towards NPIs such as use of facemask, maintaining social distancing and safe practices by people in public with their understanding may influence the growth of COVID-19.

\section{Phase-wise Lockdown in India}

- $\quad 24.03 .2020$ to 14.04 .2020 extended to 30.05 .2020 again extended till 17.05.2020

- Schools and colleges closed till 30.08.2020

- 24.03.2021 to 25.04.2021

\section{Methods}

The observational study was carried out from $31^{\text {st }}$ March 2020 to $1^{\text {st }}$ April 2021. Only 300 people were observed in Pilkhuwa, Hapur, UP, India. Everyone in the public was observed. Findings were recorded after observing the proper use of facemask, social distancing and safe practices in a crowd by people and public conversation regarding COVID-19. Data was collected from public areas such as shops, markets, bank, local transport stations, hospital OPD, etc. after visits. Collected data were segregated into segments and sub-segments based on research question, and analyzed using qualitative content analysis. The health workers or front line workers were not engaged in designing a study, research question setting, understanding or evaluating results, or research reporting. Ethical approval or consent was not required, as the study was observation related to public health concern without the involvement of people.

\section{Results}

The study findings are highlighted in Figure 1, Figure 2, and Figure 3, respectively.

\section{Facemask Practices}

\section{Wear Mask Correctly}

- Using the mask as per guidelines (Covering nostril and mouth) $15 \%$
- Mask removes while talking or sneezing or coughing though wear correctly $43 \%$

- Frequent touching of the mask though wear correctly $42 \%$

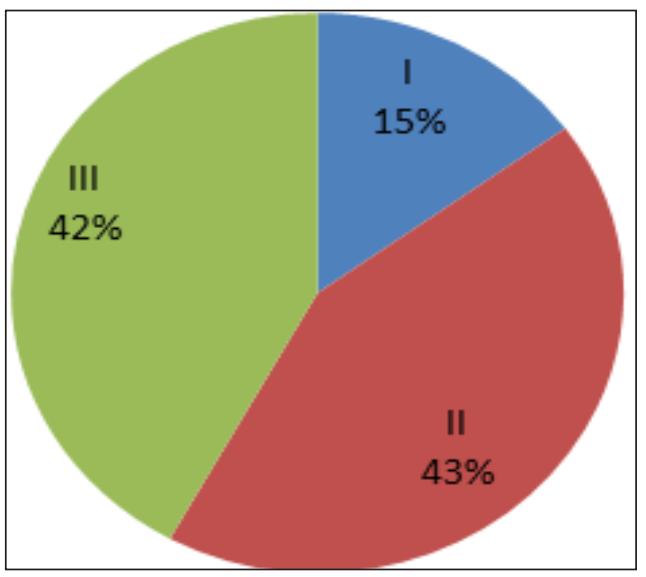

Figure I.Pie Chart of Correct Facemask Practices Wear Mask Incorrectly

- Mask covers the nose only $10 \%$

- Mask covers the mouth only $15 \%$

- Mask covers the chin only $20 \%$

- Mask wear around the neck 05\%

- Mask carrying in the hand $16 \%$

- Mask Carrying in the pocket or purse $19 \%$

- Do not use mask $15 \%$

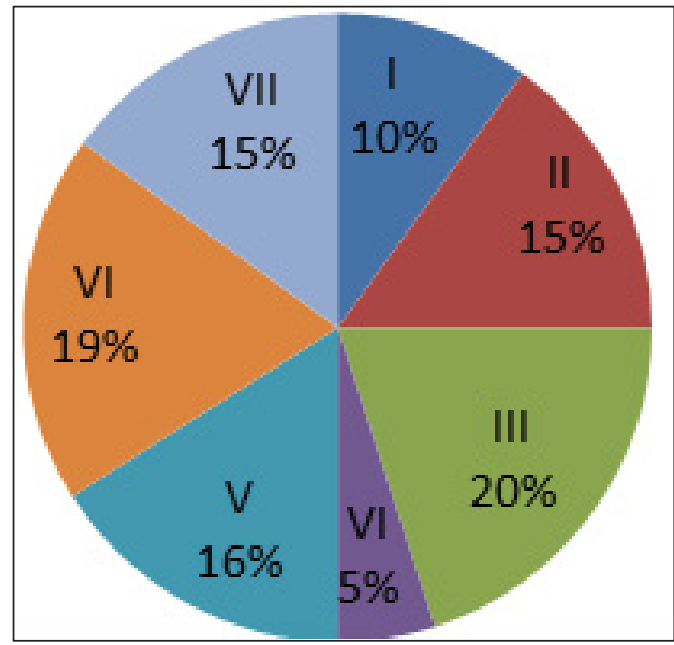

Figure 2.Pie Chart of Incorrect Facemask Practices Social Distancing Practice $\geq$ I Meter (Figure 3)

\section{Follow Measure}

Social distancing followed $\geq 1$ Meter $5 \%$.

\section{Don't Follow the Measure $95 \%$}

- Social distancing maintained $<1$ meter distance

- Social distancing is not maintained at all

- Social gathering marriage crimination, market 


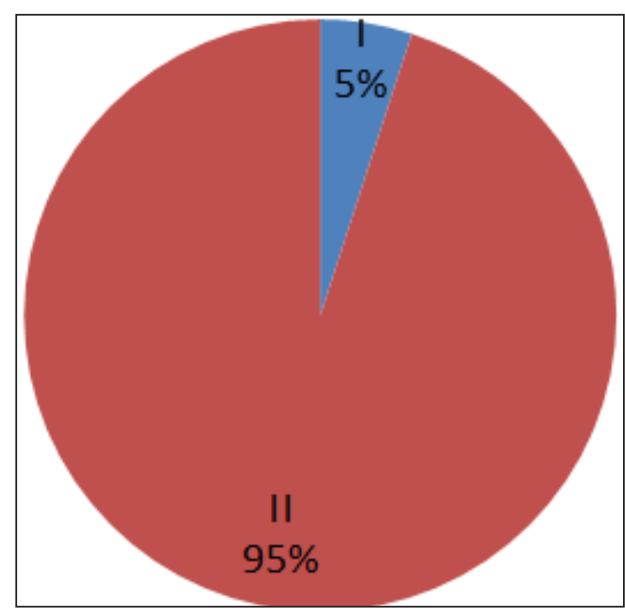

Figure 3.Pie Chart of Social Distancing

Conversation regarding COVID-I9 and Preventive Measures (Figure 4)

\section{Have Knowledge}

Mask use and social distancing prevent corona virus infection.

\section{Problem of Mask use}

- Mask causes breathing difficulty

- Mask decrease oxygen (O2) and increase the carbon dioxide (CO2)

- Mask increase the chances of infection

\section{Asymptomatic or Pre-symptomatic or Healthy Status}

- $\quad$ No need to use mask and social distancing if symptoms are absent

- If not infected, no need to use a mask and social distancing

Age

Corona virus causes problems only to elders and children.

\section{Emphasis on Social Distancing}

No need for mask use if social distancing $\geq 1$ meter maintained.

\section{Immunity}

- If maintained body immunity, corona virus cannot infect

- If vaccinated for COVID-19 than Corona virus cannot infect

\section{Freedom or Arrogance}

Would not use a mask even if got infection or chances of infection.

\section{Business of Conspiracy}

- Government is doing for business; preventive measures do not help from Corona Infection

- Corona virus is nothing new or serious but a conspiracy

\section{Avoidance of Attention}

- Carrying mask just to avoid the attention of people working for the authority

- Carrying mask just to avoid the penalty imposed by the administration

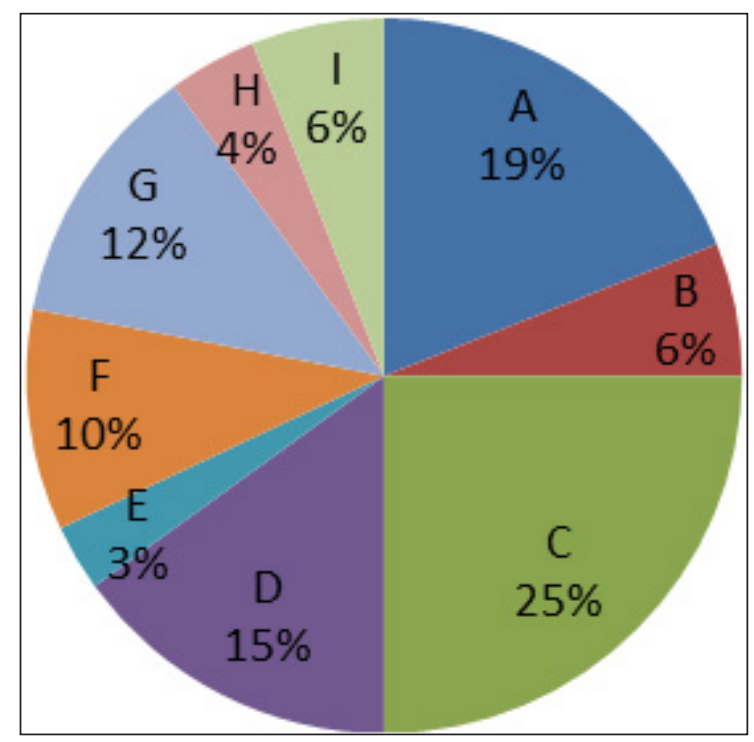

Figure 4.Pie Chart of Preventive Measures

\section{Discussion}

The severe acute respiratory syndrome corona virus (SARS-CoV-19) primarily spread among people through contact routes and respiratory droplets as based on current evidence. The later information suggested the potential airborne spread of the virus in a close environment with air recirculation. ${ }^{4}$ After that it was claimed to be airborne in close communities. The vaccination for COVID-19 also does not ensure $100 \%$ protection against the corona infection or prevention.

The NPIs are to break the transmission chain. Social distancing, even a minimum of 1 meter, has not been maintained by everyone. Social distancing practice of $<1$ meter distance reduces the chance of transmission to $12.8 \%$ and $\geq 1$ meter further reduces to $2.6 \%$ and that 2 meter distance might be more effective. ${ }^{5}$ Maintaining of a minimum 2 meter social distance has not been observed even though advised by the authority.

The findings regarding masks explain inadequate knowledge, casual attitude about the correct way to wear masks or the ignorance of people, besides the knowledge of correct use. Among those who wear masks correctly too, some do not know what should not be done after wearing the mask. Existing literature shows that proper use of facemask reduces the chance of transmission to $3.1 \%$ where facemask not in use makes transmission rise to $17.4 \%$ and irrespective of setting whether used by health care workers or people in the community. ${ }^{5}$ 
People have different understanding or views on COVID-19 and its preventive measures. The use of a facemask does not cause breathing difficulty in a healthy person. Facemask had been used by health professionals every day at work without much difficulty. People having a breathing problem, age lees than 2 years, or those who need assistance to remove the mask or incapacitated are advised not to wear the mask. ${ }^{6}$ SARS-CoV-2 is about 60-140 nanometers $(\mathrm{nm}),{ }^{7}$ which is 260 to 600 times larger than $\mathrm{CO}_{2}$ (size $0.33 \mathrm{~nm}$ ), and $\mathrm{O}_{2}$ is even smaller. ${ }^{8}$ It is unlikely that $\mathrm{CO}_{2}$ retention between the mask and face occurs to the extent that causes hypercapnia after wearing a mask. The mask still is porous enough to allow free flow of $\mathrm{CO}_{2}$ and $\mathrm{O}_{2}$ through barriers. People did not specify which types of the mask were referred. Indeed, the mask does not impact much on physiological respiratory functions after wearing for a short period among health workers. ${ }^{9,10} \mathrm{~N} 95$ mask has been found safe and comfortable for use in children at rest and on mild exertion. ${ }^{11}$ The frequent touching of mask without hand wash, which might be the explanation of wearing mask increases the chance of infection.

Symptomatic or pre-symptomatic or healthy status and age as a criterion for deciding mask use or social distancing practice by people reflect their lack of in-depth knowledge about COVID-19 transmission. The pre-symptomatic or asymptomatic period transmission is one of the drivers of epidemic growth of COVID-19. ${ }^{12-16}$ Peak viral load (infectiousness) has been observed 2 days prior to the beginning of symptom and on the first day of symptom and estimated up to $44 \%$ transmission during the cases' pre-symptomatic period with considerable family clustering, active case, and quarantine outside the home setting. ${ }^{17}$ The older are though more prone to have a serious infection, age does not prevent younger from infection. ${ }^{5}$

The emphasis on immunity or social distancing might have arisen from the fact that these preventive measures issued by authority are unfamiliar new practices in India at the community level that emphasizes alternatives over mask. The difference in social classes of people is also a very important factor in taking steps by individuals during a crisis, that is, whether stay at home or earn money to survive.

It is also observed that preventive measures were perceived as an attack on their freedom by people. COVID-19 is a serious health issue for those carrying mask just to avoid attention. Serious health issue means high mortality that could be their perception. The conspiracy or business view is reflected in the perception of people over COVID 19 situation as an attempt by the government to cover failure or as a diversion attempt.

The start of unlocking, the direction of zone wised dos and don'ts by authority gave the public kind of relaxation in their routine life. It can be assumed that it also encouraged people to disobey or abuse order, while it was being done to address the socio-economic concern. The reluctant attitude of people towards preventive measures make them infected easily in-crowd as high chances to encounter the asymptomatic infected person or act as a carrier. It also made it vulnerable to people engaged in delivering essential services due to regular exposure to the asymptomatic individual working place.

Universal use of facemask, social distancing and safe measures can considerably decrease the danger of family COVID-19 transmission irrespective of family size or crowding. ${ }^{12}$ It is also uncertain that people who are not following the preventive measures are completely healthy or not suffering any morbid condition. The interpretations of information in a different area that are reinterpreted by a second and third person have led such inaccurate or misleading information about transmission and creating information pollution. Available literature supports that a late surge of cases in the COVID-19 graph is the reflection of the public disobedient attitude since unlocking started. The late surge of the number of cases has challenged the containment measures and underscored the effectiveness of NPIs.

The limitation is that we cannot comment on the preventive measures practiced by people at home. The study did not focus on the range of people who do not follow the order of an authority.

\section{Conclusion}

The confusion due to proper information to the population, new unfamiliar practices, serious disease means high mortality perception, attack on freedom and diversion of the real issue in understanding the ongoing health crisis led disobedient attitude towards preventive measures. It is evident that the disobedience attitude caused a late surge of COVID-19 infection.

\section{References}

1. Chu DK, AkI EA, Duda S, Solo K, Yaacoub S, Schunemann HJ, COVID-19 Systematic Urgent Review Group Effort (SURGE) study authors. Physical distancing facemask and eye protection to prevent person-toperson transmission of SARS-CoV-2 and COVID-19: a systematic review and mela-analysis. Lancet. 2020 Jun 24;395(10242):1973-1987. [Google Scholar]

2. Goh DYT, Mun MW, Lee WLJ, Teoh $\mathrm{OH}$, Rajgor DD. A randomized clinical trial to evaluate the safety, fit comfort of a novel $\mathrm{N} 95$ mask in children. Scientific Reports. 2019:9(1);18952. https://doi.org/10.1038/ s41598-019-55451-w. [Pubmed] [Google Scholar]

3. He X, Lau EHY, Wu P, Deng X, Wang J, Hao X, Lau YC, Wong JY, Guan Y, Tan X, Mo X, Chen Y, Liao B, Chen W, Hu F, Zhang Q, Zhong M, Qu Y, Zhao L, Leung GM. Temporal 
dynamics in viral shedding and transmissibility of COVID-19. Nature Med. 2020:26(5);672-675. https:/doi. org/10.1038/s41591-020-0869-5. [Pubmed] [Google Scholar]

4. Hu Z, Song, C, Xu C, Jin G, Chen Y, Xu X, Ma H, Chen, W, Lin Y, Zheng, Y, Wang J, Hu Z, Yi Y, Shen H. Clinical characteristics of 24 asymptomatic Infections with COVID-19 screened [Preprint]. 2020 [cited 2021 Jun 10]. Available from: https://papers.ssrn.com/sol3/ papers.cfm?abstract_id=3543598. [Google Scholar]

5. Khalil HPSA, Saurabh CH, Syakir MI, Fazita MRN, Bhat A, Banerjee A, Fizree HM, RizalS. Tahir PM. Barrier properties of biocomposites/ hybrid films. In: Jawaid M, Thariq M, Saba N. editors. Mechanical and Physical Testing of Biocomposites, Fibrereinforced Composites and Hybrid Composites. United Kingdom: Wood head publishing; 2019. pp. 241258. [Google Scholar]

6. Kimball A, Hatfield KM, Arons M, James A, Taylor J, Spicer K, Bardossy AC, Oakley LP, Tanwer S, Chilly Z, Bell JM, Methner M, Harmey J, Jacobs JR, C1rlson CM, McLaughlin HP, Stone N, Clark S, Brostrom-Smith C, Page LC, Kay M, Lewis J, Russel D, Hiatt B, Gant J, Duchin JS, Clark TA, Hnein MA, Reddy SC, Jernigan JA. Public Health - Seattle \& King County, and CDC COVID-19 Investigation Team. Asymptomatic and Presymptomatic SARS-CoV-2 infection in resident of a long term care: skilled nursing facility - King County, Washington, March 2020. MMWR. 2020:69(13);377381. https:/ldoi.org/l0.1558S/mmwr.mm6913el. [Pubmed] [Google Scholar]

7. Roberge RJ, Coca A, Willims WJ, Palmiero AJ, Powell JB. Surgical mask placement over N95 filtering face pieee respirators: physiological effects on healthcare workers. Respirology. 2020:I5(3);S16-521. hrtpo:// doi.org/10.III/j.1440-1843.2010.01713.x. [Pubmed] [Google Scholar]

8. Roberge RJ, Coca A, Williams WJ, Powell JB, Paimmiero AJ. Physiological impact of $\mathrm{N}-95$ filtering facepiece respirator on healthcare workers. Respiratory care. 2020:55(5),569-577. [Pubmed]' [Google Scholar]

9. Shen $Y$, Li C, Dong H, Wang Z, Martinez L, Sun Z, Handel A, Chen Z, Chen E, Ebell MH, Wang F, Yi B, Wan IH. Wang $X$, Wang A, Chen B, Qi Y, Liang L, Li Y, Ling F, Chen J, Xu G. Community outbreak investigation of SARS CoV-2 transmission among bus riders in Eastem China. JAMA Internal Medicine. 2020:180(I2);1665. http://doi.org/ I0.100 / jamaintemmed.2020.5225. [Pubmed] [Google Scholar]

10. Tian H, Liu Y, Li Y, Wu C-H, Chen B, Kraemer MUG, Li B, Cai J, Xu B, Yang Q, Wang B. Yang P, Cui Y, Song Y, Zheng P, Wang Q, Bjornstad ON, Yang R, Grenfell BT, Dye C. An investigation of transmission control measures during the first 50 days of the COVID-19 epidemic in China.
Science. 2020:368(6491);638. https//doi.org/10. 1126/ science.abb6105. [Pubmed] [Google Scholar]

11. Wang $Y$, Tian $H$, Zhan L, Zhang M, Guo D, Wu W, Zhang $X$, Kan GL, Jia L, Huo D, Liu B, Wang X, Sun Y, Wang Q, Yang $P$, Macintyre CR. Reduction of secondary transmission of SARS-CoV-2 in households by facemask use, disinfection and social distancing: a cohort study in Beijing, China. BMJ Glob health. 2020:5(5);e002794. https://doi. org/10.1136/binjgh-·2020-002794. [Pubmed] [Google Scholar]

12. Wei WE, Li Z, Chie W, Yong CJ, Toh SE, Mmed, Lee VJ. Presymptomatic transmission of SARS-CoV-2Singapore, January 23 - March16, 2020. MMWR. 2020:69(14),411-5. https://doi.org/l0.15585/ mmwr,mm6914el. [Pubmed] [Google Scholar]

13. World health organization [Internet]. Advice on the use of masks in the context of COVID-19; interim guidance, 5 June 2020 [cited 2021 June 10]. Available from: https://apps.who.int/iris/handle/10665/332293. 